УДК 551.83; 552

\title{
ОБСТАНОВКИ СЕДИМЕНТАЦИИ ЛОХКОВ-НИЖНЕЭМССКИХ ВУЛКАНОКЛАСТИЧЕСКИХ ОТЛОЖЕНИЙ ЗАПАДНО-МАГНИТОГОРСКОЙ ЗОНЫ ЮЖНОГО УРАЛА
}

\author{
Зайнуллин Руслан Ишмуратович, \\ zri-bgu@mail.ru \\ 1 Институт геологии Уфимского федерального исследовательского центра Российской академии наук, \\ Россия, 450077, г. Уфа, ул. Карла-Маркса, 16/2. \\ 2 Башкирский государственный университет, \\ Россия, 450076, г. Уфа, ул. Заки-Валиди, 32.
}

Актуальность исследования. Раннедевонский этап формирования Магнитогорской островодужной системы, несмотря на многолетнюю историю исследований и достаточно большой объем полученных данных, остается малоизученным. Данному этапу соответствуют лохков-нижнеэмсские вулканокластические, карбонатные и кремнистые породы, широко распространенные на севере Западно-Магнитогорской зоны Южного Урала. Расположены они в зоне Главного Уральского разлома и поэтому подвержены вторичным изменениям, а разрезы их имеют фрагментарное строение. Вулканокластические разности, пользующиеся наибольшим распространением, практически не изучались. Исследование их и фациальных взаимоотношений между нижнедевонскими отложениями позволяет реконструировать обстановки седиментации раннедевонского бассейна и детализировать историю развития Магнитогорской островодужной системы на начальном этапе ее образования.

Цель исследования состоит в выявлении источников сноса и реконструкции обстановок седиментации нижнедевонских вулканокластических отложений Западно-Магнитогорской зоны Южного Урала.

Методы. Реконструкция обстановок накопления проведена на основе изучения структурно-текстурных особенностей, минералого-петрографического и литогеохимического состава вулканокластических пород и корреляции нижнедевонских отложений по биостратиграфическим данным. Полученные результаты сопоставлялись с данными ведущих исследователей по современным обстановкам седиментации.

Результаты. Нижнедевонские вулканокластические отложения Западно-Магнитогорской зоны Южного Урала являются турбидитами и дебритами. Они сложены преимущественно пирокластическим и вулканотерригенным материалом основного и среднего состава. Впервые показано, что накопление их происходило в проксимальной и дистальной части островной дуги. В дистальной части накапливались отложения ильтибановской и мансуровской толщ, в проксимальной - ускульской и рыскужинской толщ. Формирование Магнитогорской островодужной системы могло начаться в раннеэмсское время или даже раньше.

\section{Ключевые слова:}

Вулканокластические отложения, нижний девон, островная дуга, Магнитогорская мегазона, Южный Урал.

\section{Введение}

На севере Западно-Магнитогорской зоны (ЗМЗ) широко распространены лохков-нижнеэмсские отложения рыскужинской, ускульской, ильтибановской и мансуровской толщ [1] (рис. 1). Они состоят из вулканокластических, карбонатных, кремнистых пород и реже вулканитов, расположенных в зоне Главного Уральского разлома или в непосредственной близости от нее. Поэтому отложения часто подвержены вторичным изменениям, а разрезы их имеют фрагментарное строение. В связи с малым количеством находок фауны лохков-нижнеэмсские отложения раньше картировали в составе ирендыкской свиты среднего девона. В настоящее время, благодаря детализации стратиграфии нижнедевонских отложений $3 \mathrm{M} 3$ [1], появилась возможность подробно изучать литологические особенности пород, сравнивать одновозрастные толщи и восстанавливать обстановки их накопления.

Вышеперечисленные нижнедевонские толщи редко образуют непрерывные разрезы. Нижняя и верхняя границы их чаще всего тектонические. Перекрывают их отложения баймак-бурибаевской или ирендыкской свит ранне-среднедевонского возраста. Подстилающие отложения силурийского возраста на дневной поверхности обнажены редко.
Изучение вулканокластических отложений производилось в Вознесенско-Присакмарской и Узынкырской подзонах ЗМЗ при описании 10 перспективных участков, включающих 16 разрезов.

\section{Строение разрезов нижнедевонских отложений}

Вулканокластические отложения среди нижнедевонских пород пользуются наибольшим распространением. Они представлены песчаниками, алевролитами, гравелитами, крупно- и грубообломочными микститами, которые часто слагают турбидиты и дебриты [2, 3] (рис. 2 а, б). В строении разрезов рыскужинской и ускульской толщ, участвуют кластолиты главным образом псаммитовой и алевритовой размерности и аргиллиты. Они образуют турбидиты мощностью $0,3-0,5$ и реже 1 м. В свою очередь, разрезы ильтибановской и мансуровской толщ, состоят преимущественно из грубо- и крупнозернистых песчаников и псефитовых микститов, слагающих турбидиты и дебриты, мощностью $0,15-0,2,0,4-2$ и 3-8 м соответственно. В основании турбидитов (в крупно- и грубозернистых песчаниках) иногда встречаются обломки кремнистых аргиллитов гравийной размерности. Дебриты состоят из плохо сортированных неокатанных грубозернистых фрагментов вулканитов 
песчаной размерности, среди которых присутствуют гравийно-галечные обломки силицитов и известняков, реже их отломы и глыбы. Обломки расположены хаотически и иногда ориентированы длинной осью параллельно подошве.

В разрезах рыскужинской и ускульской толш, также встречаются единичные слои песчаников мощностью $0,15-0,3$ м, содержащих большое количество остатков макрофауны - брахиопод, криноидей и гастропод (рис. 2, в-e). В рыскужинской толще брахиоподы имеют раннеэмсский возраст [4], в ускульской - пражско-эмсский (определения выполнены Л.И. Мизенс, ИГГ УрО РАН). Помимо этого, в данных толщах пачки кластолитов иногда чередуются с массивными и брекчиевыми плагиоклазовыми и пироксен-плагиоклазовыми порфиритами (лавовыми потоками) мощностью примерно 3-15 м. В строении разрезов ильтибановской $и$ мансуровской толщ, потоки вулканитов не обнаружены, состоят они преимущественно из обломочных образований, которые чередуются с кремнями и кремнисто-глинистыми сланцами.

Крелнистые и крелнисто-глинистые породы представлены светло-серыми, серыми тонкослоистыми, плитчатыми и рассланцованными разностя- ми. Присутствуют во всех перечисленных толщах. Они образуют среди кластолитов слои мощностью 0,3-1 м и более или слагают пачки и фрагменты разрезов мощностью 50-60 и 250-400 м соответственно. Кремни датированы конодонтами лохковского, пражского и раннеэмсского возраста [4].

Известняки белые, светло-серые, серые массивные и реже рассланцованные, иногда мраморизованные. Образуют тела (биогермы (?)), расположенные преимущественно среди обломочных отложений рыскужинской и ускульской толщ. В разные годы в них найдены кораллы (табуляты, ругозы), брахиоподы, стебли и членики криноидей и конодонты. Согласно фаунистической характеристике, известняки принадлежат двум стратиграфическим интервалам девонского разреза - пражско-нижнеэмсскому и реже лохковскому $[1,5,6]$. Тела известняков имеют субмеридиональное простирание, ширина их составляет примерно 100-500 м, длина - более 500-1000 м. В некоторых из тел обнаружены слои и пачки вулканокластических песчаников и алевролитов [6]. Контакты с окружающими их отложениями описываются в основном как тектонические и, в редких случаях, как согласные [1, 6 и др.].

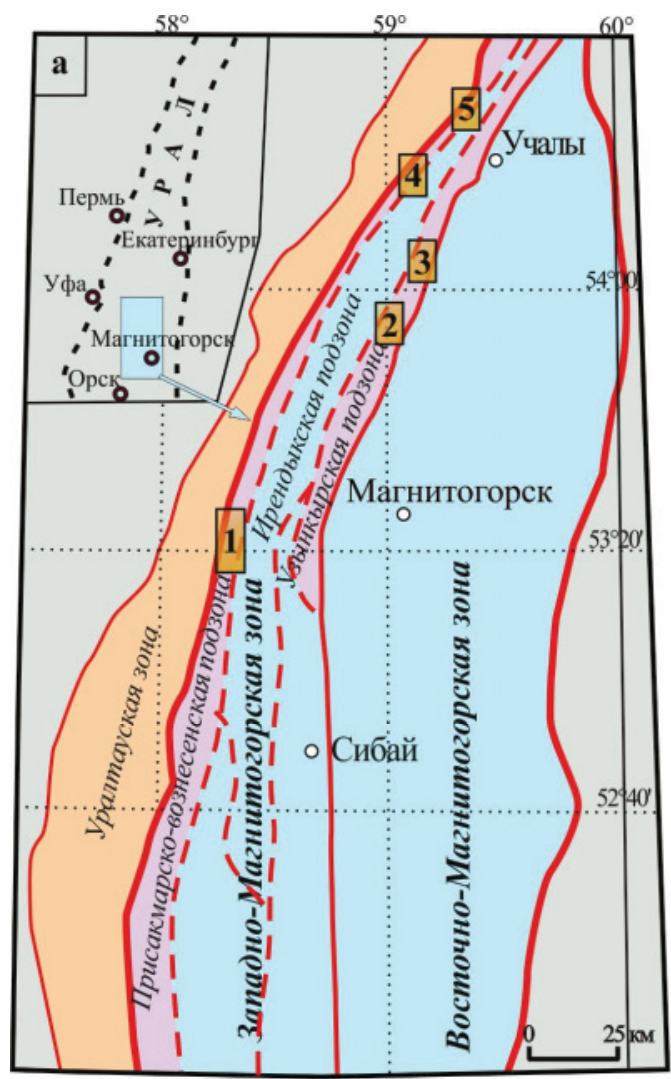

\begin{tabular}{|c|c|c|c|}
\hline 点 & 윰 & \multicolumn{2}{|c|}{$\begin{array}{c}\text { Западно-Магнитогорская } \\
\text { структурно-формационная зона }\end{array}$} \\
\hline \multirow{2}{*}{ 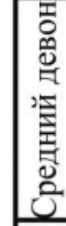 } & \multirow{2}{*}{ 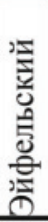 } & \multicolumn{2}{|c|}{$\begin{array}{l}\text { ярлыкаповская свита: яшмоиды } \\
\qquad(20-100 \text { м })\end{array}$} \\
\hline & & \multicolumn{2}{|c|}{$\begin{array}{c}\text { ирендыкская свита: } \\
\text { базальты, андезибазальты, туфы, тефроиды } \\
\text { (до } 1200 \text { м) } \\
\end{array}$} \\
\hline 핑 & 产 & $\begin{array}{c}\text { ильтибановская и } \\
\text { мансуровская } \\
\text { толщи: }\end{array}$ & $\begin{array}{c}\text { аналоги } \\
\text { баймак-буриба- } \\
\text { евской свиты } \\
---------\overline{-} \\
\text { рыскужинская и } \\
\text { ускульская } \\
\text { толщи: }\end{array}$ \\
\hline 突 & 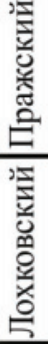 & $\begin{array}{l}\text { вулканокластические } \\
\text { песчаники, алевролиты } \\
\text { микститы, кремнисто- } \\
\text { глинистые сланцы }\end{array}$ & $\begin{array}{c}\text { вулканокласти- } \\
\text { ческие песча- } \\
\text { ники, алевроли- } \\
\text { ты, гравелиты, } \\
\text { аргиллиты, } \\
\text { известняки и } \\
\text { реже вулканиты } \\
\\
(300-700 \text { м) }\end{array}$ \\
\hline
\end{tabular}

Pис. 1. Схема районирования Магнитогорской мегазоны и расположение разрезов нижнедевонских отложений (a): 1 - рыскужинской, 2, 3 - ускульской, 4 - ильтибановской и 5 - мансуровской толщ; стратиграфическая схема нижне-среднедевонских отложений $3 \mathrm{M} 3$ (б)

Fig. 1. Scheme of zoning of the Magnitogorsk megazone and location of the sections of the Lower Devonian deposits (a): 1-ryskuzhinskaya, 2, 3 - uskul, 4 - iltibanovskaya and 5 - mansurovskaya strata; stratigraphic scheme of the Lower-Middle Devonian deposits of ZMZ (b) 


\section{Состав и источники сноса}

вулканокластических отложений

Вулканокластические отложения сложены слабо окатанными и неокатанными литокластами вулканитов основного и среднего состава, кристаллокластами плагиоклаза, реже пироксена и кварца. Состав их в нижнедевонских толщах различается. Например, в песчаниках ускульской толщи немного выше (на 5-10 \% ) содержание кристаллокластов пироксена и обломков пироксен-плагиоклазовых порфиритов. В свою очередь песчаники рыскужинской толщи состоят преимущественно из кристаллокластов плагиоклаза, обломков плагиоклазовых порфиритов и единичных зерен кислых вулканических пород и габбродиоритов. Кластолиты ильтибановской и мансуровской толш, имеют более пестрый состав и сложены главным образом плагиоклазовыми порфиритами (60-70\%), кристаллокластами плагиоклаза (10-20\%), реже кварца (в т. ч. его поликристаллическими разновидностями) (5-7 \% ), единичны- ми зернами пироксена, а также обломками (менее $15 \%$ ) известняков, силицитов и кремнисто-глинистых сланцев.

Окатанность обломков пород во всех толщах соответствует $0,1,2$ и реже 3 баллам по шкале А.В. Хабакова. Сортировка кластики плохая, средняя и, реже, хорошая, упаковка зерен плотная. Цемент в песчаниках глинистый и глинистохлоритовый. Вторичные процессы проявлены в виде эпидотизации, хлоритизации, альбитизации и карбонатизации.

Сравнение минералого-петрографических составов изучаемых пород и современных вулканогенных осадков показало [7], что вулканокластические отложения рыскужинской и ускульской толщ, скорее всего, сложены преимущественно пирокластическим материалом, который после выпадения перемещался по склону вулканической постройки турбидными потоками, т. е. представляют собой тефроиды или тефротурбидиты. Обломочные отложения ильтибановской и мансуровской
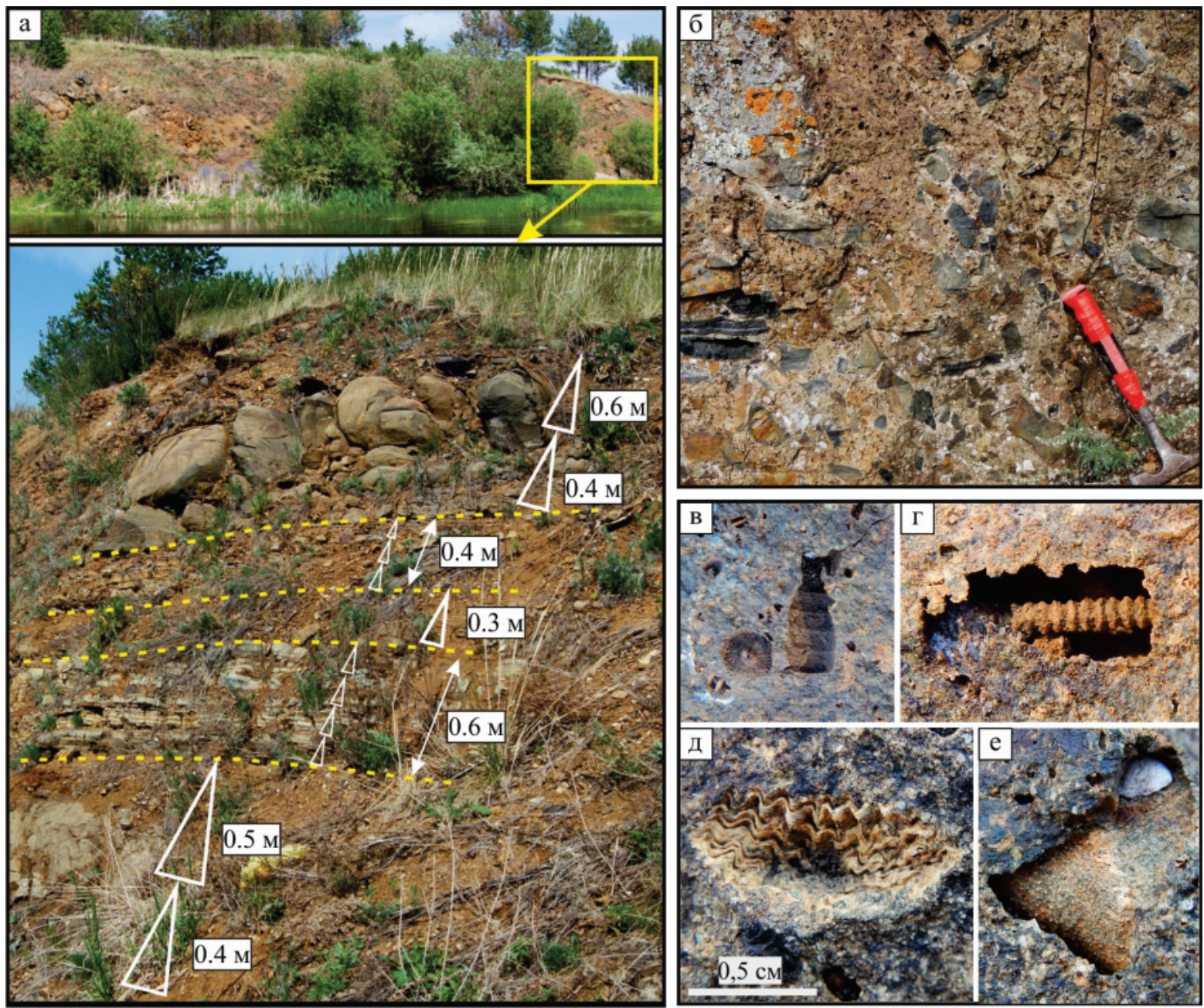

Рис. 2. Фрагмент разреза ильтибановской толщи с турбидитами (а) и дебритами (б) разной мощности, а также криноидеи $(B, г)$ и брахиоподы (д, е) и их отпечатки в турбидитах ускульской толщи

Fig. 2. Fragment of the section of the itlibanovaya strata with turbidite (a) and debris deposits (6) of different thickness, as well as crinoids $(B, \Gamma)$ and brachiopods $(Z, e)$ and their imprints in turbidites of the uskul strata 
толщ состоят преимущественно из вулканотерригенного (вулканомиктового) материала, транспортировка которого осуществлялась также турбидными и чаще обломочными потоками.

Содержание химического состава, проанализированное ранее [3], позволяет считать, что нижнедевонские вулканокластические отложения сложены породообразующими компонентами основ- ного и среднего состава (базальтового и андезибазальтового). Хорошо это наблюдается на диаграмме $\mathrm{Nb} / \mathrm{Y}-\mathrm{Zr} / \mathrm{TiO}_{2}$ [8], где фигуративные точки пород всех толщ компактно расположились в одном поле (рис. 3, a).

Согласно геодинамическим реконструкциям [3], источником вещества для изучаемых пород служила океаническая островная дуга. Объясняет-
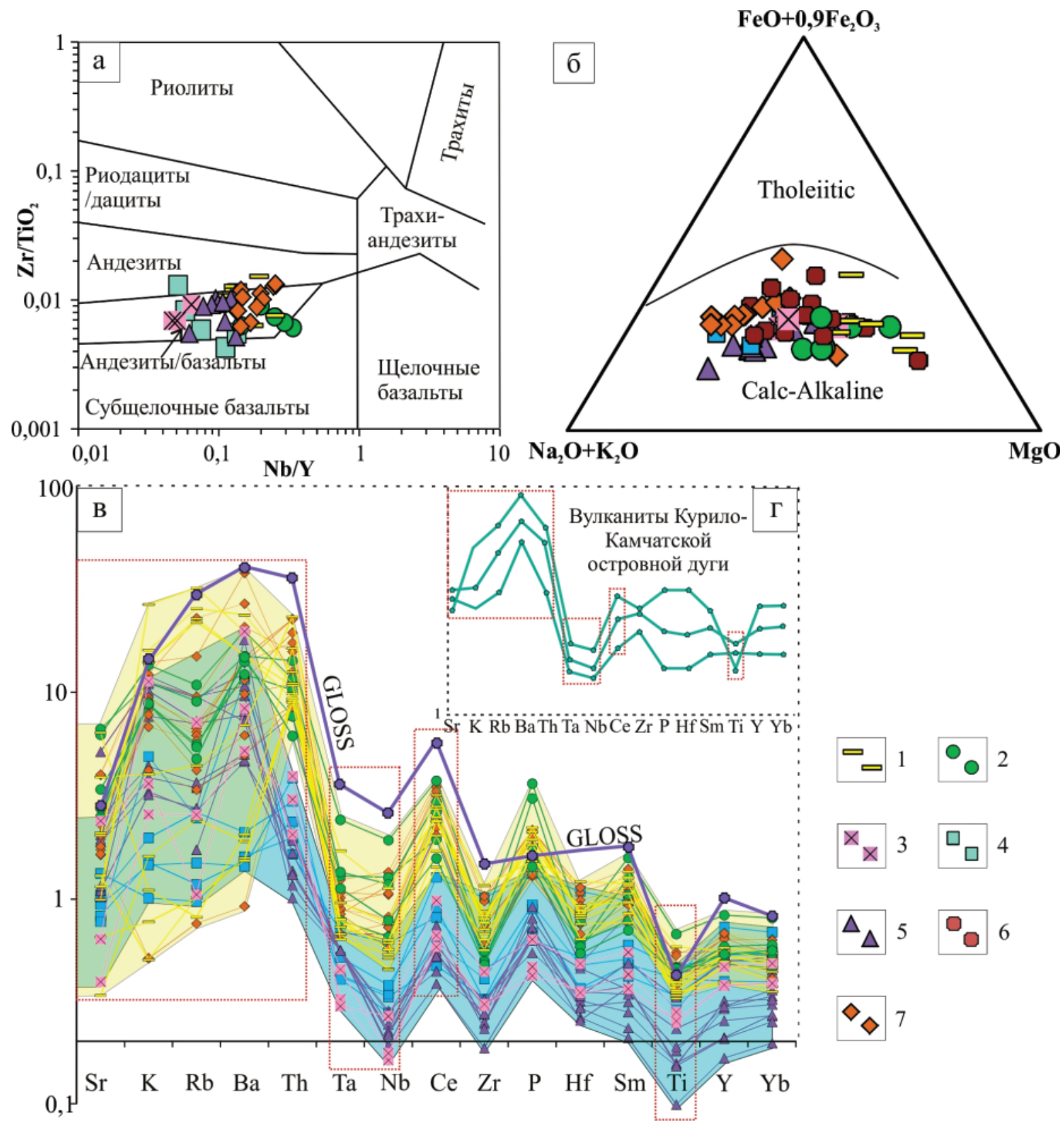

Рис. 3. Диаграммы для определения состава $(a, 6)$ и геодинамических обстановок формирования $(B, r)$ нижнедевонских вулканокластических отложений. Условные обозначения: кластолиты разрезов дд. Тирман (1), Рыскужино (2), Казмашево (3) - рыскужинская толща; оз. Ускуль (4) и д. Уразово (5) - ускульская толща; д. Мансурово (6) - мансуровская толща и Ильтибановского водохранилища (7) - ильтибановская толща; GLOSS - global subduction sediment (средний состав осадков из глобальных зон субдукции)

Fig. 3. Diagrams for determining the composition $(a, 6)$ and geodynamic environments of formation $(B, \Gamma)$ of the Lower Devonian volcaniclastic deposits. Legend: clastoliths of sections in villages Tirman (1), Ryskuzhino (2), Kazmashevo (3) - ryskuzhinskaya stratum; lake Uskul (4) and the village Urazovo (5) - uskulskaya strata; Mansurovo (6) - mansurovskaya stratum and iltibanovskaya reservoir (7) - itlibanovskaya stratum; GLOSS - global subduction sediments 
ся данный вывод тем, что кластолиты характеризуются низкими содержаниями титана, хрома и никеля, относятся к известково-щелочной серии и спектры малых элементов, нормированных на $\mathrm{N}$-MORB, имеют схожее расположение со спектрами вулканитов современных островных дуг, например Курильской [9-11] (рис. 3, в, г). На диаграмме N-MORB хорошо выражены повышенные содержания некогерентных элементов, отрицательные геохимические аномалии $\mathrm{Ta}-\mathrm{Nb}, \mathrm{Zr}$, Ti и положительные - Ce.

\section{Характеристика и особенности развития раннедевонского бассейна}

Формирование нижнедевонских отложений происходило в седиментационном бассейне, который описывается в работе [12] как ранне-среднеде- вонский преддуговой. Достаточно разнообразный литологический состав и генезис нижнедевонских пород свидетельствует о дифференцированной глубине и неоднородности рельефа данного бассейна и существовании в нем различных седиментационных обстановок и источников сноса.

В раннедевонское время накопление вулканокластических отложений, возможно, происходило вокруг вулканических центров островной дуги в виде покровов, конусов выноса (fans) и мощных шлейфов в глубоководной части бассейна. Согласно многочисленным исследованиям [13-20 и др.], считается, что вблизи вулканического иентра накапливаются лавовые потоки, разнозернистые вулканокластические отложения, продукты их дезинтеграции и образуются различные интрузивные тела и рифогенные известняки. Вдали от иен-
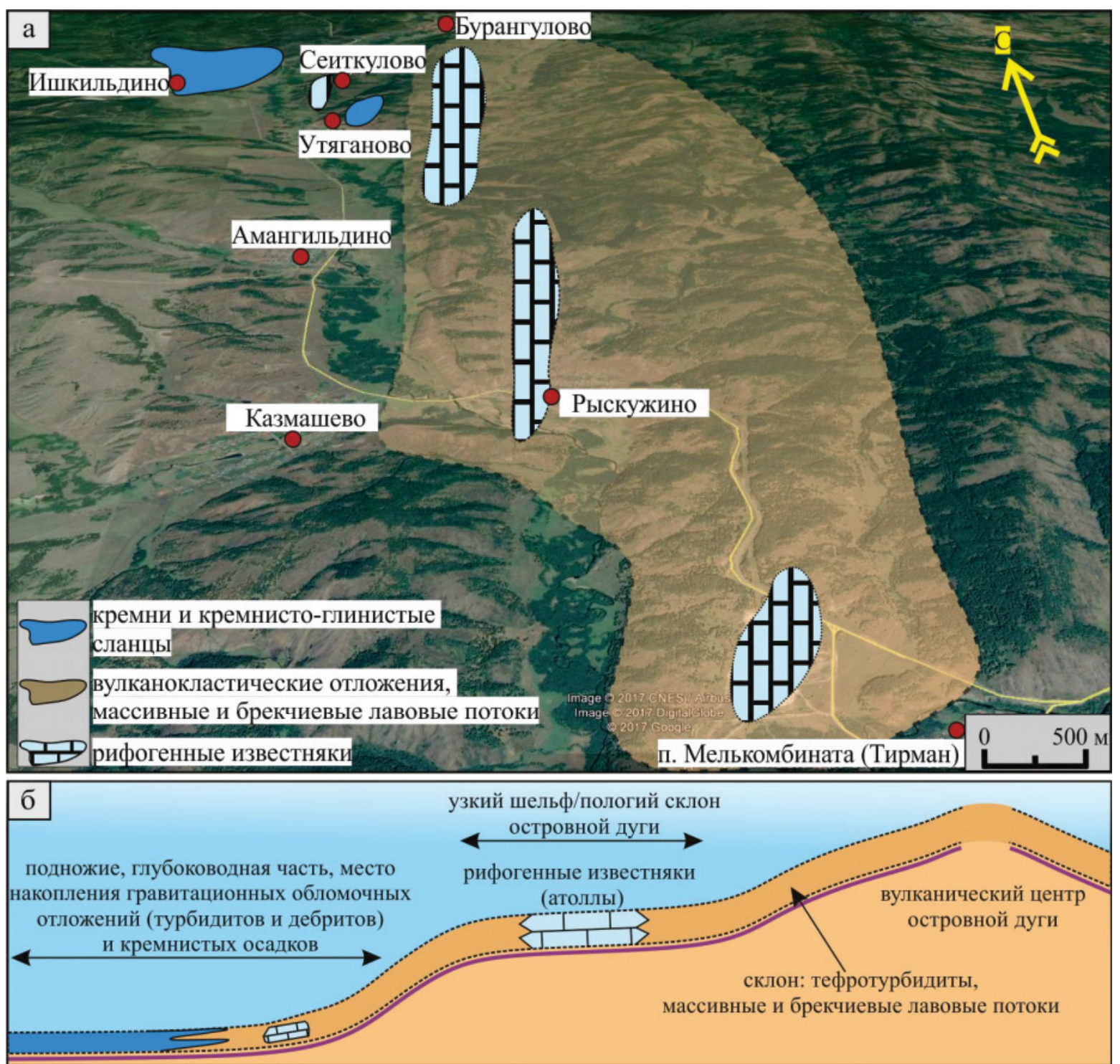

Pис. 4. Схематичная карта распространения отложений рыскужинской толщи (а) и идеализированная модель обстановок седиментации и строения вулканического центра островной дуги раннеэмсского времени (б) (масштабы разные)

Fig. 4. Schematic map of location of the ryskuzhinsky deposit (a) and idealized model of sedimentation and structure of the volcanic center of the island arc of the early ems (6) (different scales) 
тра лавовые потоки и интрузивные породы исчезают, а вулканогенные осадки становятся более тонкозернистыми. Поэтому можно предположить, что накопление тефротурбидитов, массивных и брекчиевых лавовых потоков и известняков рыскужинской и ускульской толш, происходило на склонах и у подножий вулканических центров (т. е. в проксимальной части) (рис. 4,5$)$.

Согласно результатам минералого-петрографических и химических исследований и расположению разрезов, обломочные отложения рыскужинской и ускульской толщ имели разные источники сноса, т. е. накапливались вокруг разных вулканических центров единой дуги, находившихся, примерно, на таком же расстоянии, которое есть сегодня между стратотипическими разрезами этих толщ 65-70 км. Такие расстояния наблюдаются между островами Курильской, Марианской и других дуг.

В более глубоководной части островной дуги (в дистальной части) в виде конусов выноса и шлейфов формировались обломочные отложения $и л ь т-$ ибановской и мансуровской толщ. Объясняется это тесной ассоциацией их с глубоководными массивными и тонкослоистыми силицитами и кремнисто-глинистыми сланцами, а также отсутствием мелководных отложений (с характерными текстурами), в том числе распространенных в проксимальной части островной дуги - лавовых потоков и рифогенных известняков (могут присутствовать только в виде обломков и глыб) (рис. 5).

Биостратиграфические данные (полный список источников в [1]) позволяют условно разделить формирование нижнедевонских отложений ЗМЗ на два этапа - позднесилурийско-лохковский и пражско-раннеэмсский (рис. 5).

Позднесилурийско-лохковское время. В северной части бассейна (здесь и далее в современных координатах) в относительно глубоководной обстановке происходило активное накопление вулканокластических дебритов и турбидитов, а также кремнистых и кремнисто-глинистых осадков ильтибановской и мансуровской толщ. По мнению Г.А. Мизенса [21], при формировании девонских вулканогенно-осадочных толщ Магнитогорской зоны могли размываться аналоги силурийско-раннедевонской островной дуги. Поэтому нельзя исключать, что источником вещества для вулканокластических отложений ильтибановской и мансуровской толщ могли служить размываемые комплексы вышеупомянутой островной дуги. В свою очередь И.С. Анисимов [22] считал, что отложения мансуровской и ильтибановской толщ представляют собой мелко-среднеобломочную олистострому, формирование которой связано с начальными этапами заложения и развития Магнитогорской (Ирендыкской) островной дуги.

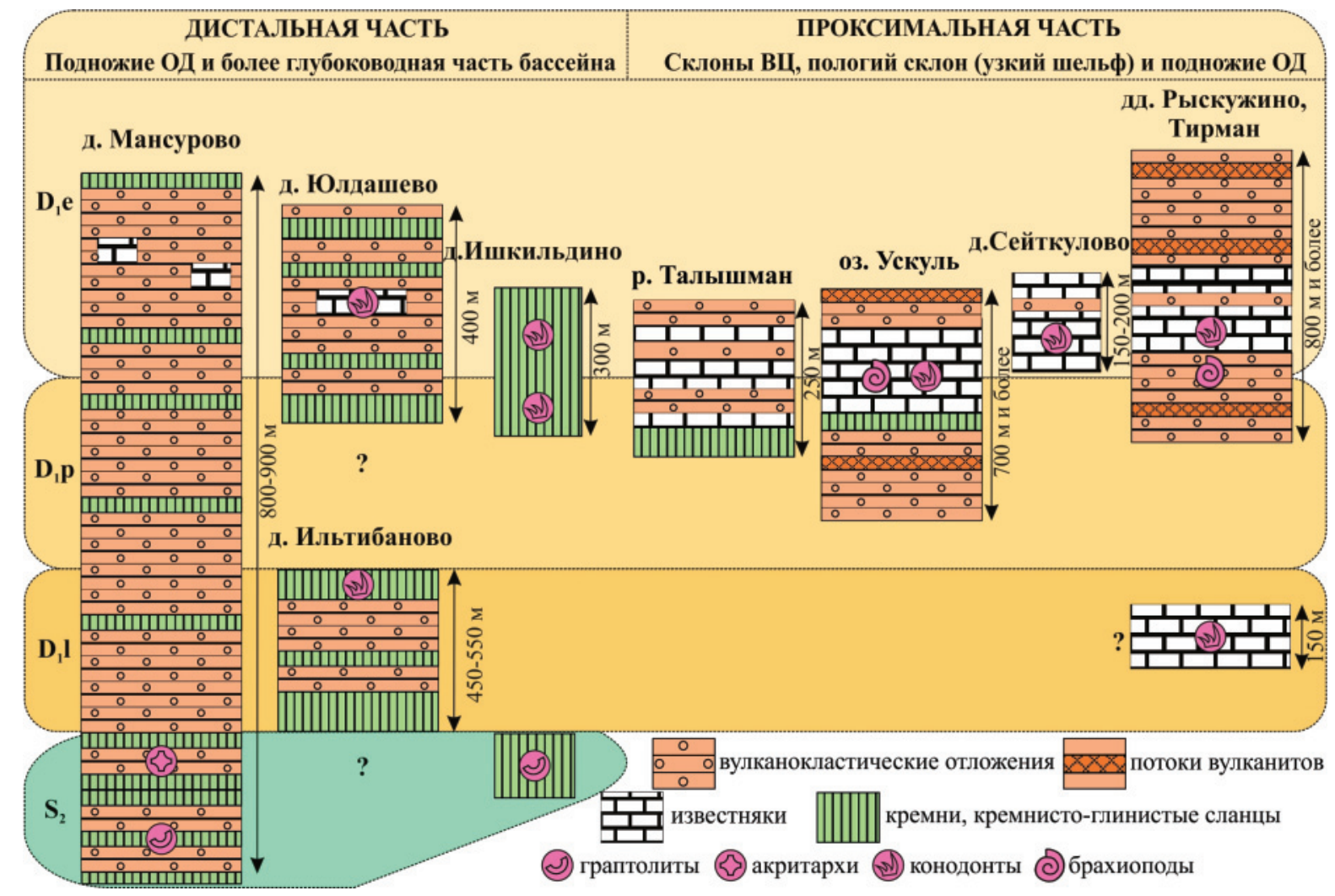

Рис. 5. Время формирования и обстановки седиментации нижнедевонских отложений Западно-Магнитогорской зоны. Сокращения: ВЦ - вулканические центры, ОД - островная дуга

Fig. 5. Time of formation and environment of sedimentation of lower Devonian deposits of the West-Magnitogorsk zone. Abbreviations: ВЦ - volcanic centers, ОД - island arc 
В южной части бассейна, в районе распространения отложений рыскужинской толщи, в данное время, видимо, происходило образование известняков и накопление кремнисто-глинистых осадков.

Пражско-раннеэмсское время. Недостаточность палеонтологических находок пражского возраста затрудняет проведение каких-либо реконструкций бассейна этого времени. Можно лишь предположить, что большинство отложений, датированных раннеэмсской фауной, могли начать формироваться немного раньше, в том числе и в пражское время, т. к. нижние границы (время начала формирования) их не установлены.

В данный период в северной части бассейна в глубоководной зоне продолжалось накопление вулканокластических дебритов и турбидитов и кремнистых осадков ильтибановской и мансуровской толщ. Количество и частота поставляемого вулканокластического материала могла сокращаться, что приводило к увеличению кремненакопления (разрез у д. Юлдашево).

В связи с началом образования и действия Магнитогорской энсиматической островной дуги произошло перестроение территории и изменение рельефа дна бассейна, что привело, возможно, к более резкому обособлению обстановок, различающихся глубиной. Например, в западной части бассейна (разрезы дд. Ишкильдино и Утяганово), в относительно более глубоководной зоне, активнее начали накапливаться кремнистые осадки рыскужинской толщи. Наоборот, в восточной части бассейна, после того как сформировался стабильный рельеф юной островной дуги с узким пологим склоном (шельфом), возможно, началось активное накопление известняков. Подтверждением этого, в определенной степени, являются исследования А.М. Фазлиахметова, указывающие, что формирование нижнедевонских известняков происходило на активной континентальной окраине [5]. Скорее всего, в данный небольшой отрезок раннеэмсского времени вулканической активности не было или она была слабой и существенно не влияла на карбонато- и кремненакопление. Кратковременные и маломощные извержения лишь на некоторое время прерывали формирование карбонатных пород, что подтверждается наличием небольших слоев и пачек вулканокластических песчаников и алевролитов в известняках рыскужинской толщи и у д. Баталово. Поэтому, учитывая данное обстоятельство, а также то, что известняки находятся в тесной ассоциации с островодужными вулканокластическими отложениями, можно предположить, что они окаймляли вулканические центры в виде рифогенных построек (sensu lato), часто подвергаемых разрушению гравитационными потоками или волновыми процессами различной природы. В результате образовывался обломочный карбонатный материал, содержащий большое количество макрофауны, который сносился в глубоководные зоны бассейна и накапливался совместно с тефротурби- дитами вышеназванных толщ (разрезы Рыскужино и Ускуль). Учитывая, что для благоприятного формирования рифов требуются особые условия и рельеф, видимо, островодужные вулканические постройки с узким шельфом (относительно пологой поверхностью) уже были подготовлены. Примером могут служить современные действующие вулканические центры Марианской дуги (например, Аламаган), где созданы благоприятные условия для развития коралловых рифов (по данным Benthic Habitat Pacific Islands). В последующем вулканические центры продолжили активно действовать, на их склонах и подножиях формировались преимущественно тефротурбидиты, массивные и брекчиевые лавовые потоки и в связи с этим, возможно, прекратилось карбонатонакопление рыскужинской и ускульской толщ. В эмсское время с юной островной дуги вулканокластический материал, обломки и блоки известняков гравитационными потоками также начали поступать в ту часть бассейна, где накапливались отложения ильтибановской и мансуровской толщ (верхние части разрезов Юлдашево и Мансурово).

Таким образом, изучаемый раннедевонский бассейн характеризовался не только длительной тектонической паузой и накоплением преимущественно осадочных пород, как считалось ранее $[23,24]$, но и мобильным тектоническим режимом с периодами активного формирования относительно большого количества тефрогенного и вулканотерригенного материала.

\section{Заключение}

Изучение нижнедевонских вулканокластических отложений ЗМЗ и других пород, находящихся в тесной ассоциации с ними, позволило приурочить их накопление к проксимальной и дистальной части островной дуги.

Согласно палеотектоническим реконструкциям, в раннем девоне на данной территории произошло формирование Магнитогорской островодужной системы. Начальные стадии ее образования связывают главным образом с позднеэмсским баймак-бурибаевским вулканизмом [1, 24, 25 и др.]. Но на сегодняшний день не установлена нижняя граница баймак-бурибавеской свиты [1] и соответственно неизвестно время начала формирования слагающих ее пород и островодужной системы в целом. Поэтому новые данные, полученные автором по породам, расположенным, предположительно, ниже баймак-бурибаевской свиты, и материалы, указывающие на наличие в ЗМЗ магматических комплексов лохков-эмсского возраста с островодужной химической специализацией [26-28], позволяют считать, что формирование Магнитогорской островодужной системы могло начаться в раннеэмсское время или даже раньше. Это привело к образованию под водой расчлененного положительного рельефа и преддугового бассейна с латеральными рядами седиментационных обстановок. В результате произошло накопление разнородных ти- 
пов отложений - глубоководных кремней и кремнисто-глинистых сланцев, вулканокластических (тефрогенных, вулканотерригенных) дебритов и турбидитов, массивных и брекчиевых склоновых

\section{СПИСОК ЛИТЕРАТУРЫ}

1. Маслов В.А., Артюшкова 0.В. Стратиграфия и корреляция девонских отложений Магнитогорской мегазоны Южного Урала. - Уфа: ДизайнПолиграфСервис, 2010. - 288 с.

2. Зайнуллин Р.И. Особенности состава и строения вулканокластических отложений нижнего девона северной части ЗападноМагнитогорской зоны Южного Урала // Уникальные литологические объекты через призму их разнообразия: 2-я Всероссийская школа студентов, аспирантов и молодых ученых по литологии. - Екатеринбург, 2016. - С. 122-124.

3. Зайнуллин Р.И. Состав и особенности формирования вулканокластических отложений нижнего девона Западно-Магнитогорской зоны Южного Урала // Литосфера. - 2017. - Т. 17. № 2. - С. 78-94.

4. Первые находки брахиопод в вулканогенно-осадочных породах ирендыкской свиты на Южном Урале / К.С. Иванов, А.З. Бикбаев, Л.И. Мизенс, В.П. Сапельников // Ежегодник 1996. Информационный сборник научных трудов. - Екатеринбург: ИГГ Ур0 РАН, 1997. - С. 13-15.

5. Фазлиахметов А.М., Артюшкова 0.В. Условия формирования раннеэмсских известняков восточного склона Южного Урала по геохимическим данным / / Осадочная геология Урала и прилежащих регионов: сегодня и завтра. Материалы 12 Уральского литологического совещания. - Екатеринбург: ИГГ Ур0 PAH, 2018. - C. 355-359.

6. Павлов В.В. Геологическое строение и полезные ископаемые Юлдашевской площади // Отчет о геологическом доизучении в масштабе 1:50000 за 1983-1988 гг. - Уфа: Башкиргеология, 1988. - 435 с.

7. Зайнуллин Р.И. Нижнедевонские вулканокластические отложения Западно-Магнитогорской зоны Южного Урала // Геология, география и глобальная энергия. - 2017. - № 4. - С. 74-89.

8. Winchester J.A., Floyd P.A. Geochemical discrimination of different magma series and their differentiation products using immobile elements // Chem. Geol. - 1977. - V. 20. - P. 325-343.

9. Фролова Т.И., Бурикова И.А. Магматические формации современных геотектонических обстановок. - М.: МГУ, 1997. - 320 с.

10. Martynov A.Y., Martynov Y.A. Pleistocene basaltic volcanism of Kunashir Island (Kuril island arc): Mineralogy, geochemistry, and results of computer simulation // Petrology. - 2017. № 2. - P. 206-225.

11. Pearce J.A. Role of the sub-continental lithosphere in magma genesis at active continental margins // Continental basalts and mantle xenoliths / Eds. C.J. Hawkesworth, M.J. Norry. Nantwich: Sica Publ., 1983. - P. 230-249.

12. Мизенс Г.А., Свяжина И.А. 0 палеогеографии Урала в девоне // Литосфера. - 2007. - № 2. - С. 29-44.

13. Dickinson W.R. Sedimentation of volcaniclastic strata of the Pliocene Koroimavua Group in northwest Viti Levu, Fiji, Am // J. Sci. - 1968. - V. 266. - P. 440-453.

14. Mitchell A.H.G. Facies of an early Miocene volcanic arc, Malekula Island, New Hebrides // Sedimentology. - 1970. - V. 14. P. 201-243. лавовых потоков и рифогенных известняков - изучаемых толщ.

Исследования выполнены по теле государственного задания № AAAA-A16-116090210010-5.

15. Carey S., Sigurdsson H. A model of volcanogenic sedimentation in marginal basins. - London: Geological Society, 1984. - Special Publications. - V. 16. - P. 37-58.

16. Carey S. Modeling of Tephra Fallout from Explosive Eruptions // Monitoring and Mitigation of Volcano Hazards. - Berlin: Springer-Verlag Berlin Heidelberg, 1996. - P. 429-461.

17. Fisher R. Submarine volcaniclastic rocks. - London: Geological Society, 1984. - Special Publications. - V. 16. - P. 5-27.

18. Suthren R.J. Facies analysis of volcaniclastic sediments: a review. - London: Geological Society, 1985. - Special Publications. - V. 18. - P. 123-146.

19. Einsele G. Sedimentary basins: evolution, facies, and sediment budget. - Berlin Heidelberg: Springer, 2000. - 792 p.

20. Einsele G. Sedimentary basins: evolution, facies, and sediment budget. - Berlin Heidelberg: Springer, 1992. -628 p.

21. Мизенс Г.А. Редкие элементы и особенности источников сноса обломочного материала осадочных формаций девона и карбона в восточных зонах Южного Урала // Геохимия. - 2009. № 12. - C. 1259-1278.

22. Анисимов И.С. Мансуровская толща: ее строение и положение в геологическом разрезе девона // Геология, полезные ископаемые и проблемы геоэкологии Башкортостана, Урала и сопредельных территорий: материалы 9-й Межрегиональной научно-практической конференции. - Уфа, 2012. - С. 3-6.

23. Артюшкова 0.В., Маслов А.В. Нижнедевонские (доверхнеэмсские) отложения Магнитогорской мегазоны // Геологический сборник № 2. - Уфа: ИГ УНЦ РАН, 2001. - С. 80-87.

24. Косарев А.М., Пучков В.Н., Серавкин И.Б. Петролого-геохимические особенности раннедевонско-эйфельских островодужных вулканитов Магнитогорской зоны в геодинамическом контексте // Литосфера. - 2005. - № 4. - С. 22-41.

25. Seravkin I.B., Kosarev A.M., Puchkov V.N. Geodynamic conditions of formation of massive sulfide deposits in the Magnitogorsk Megazone, Southern Urals, and prospection criteria // Geology of Ore Deposits. - 2017. - № 3. - P. 227-243.

26. Этапы палеозойского интрузивного магматизма Уральского орогена и их геодинамическая интерпретация. Геодинамика, магматизм, метаморфизм и рудообразование / Г.Б. Ферштатер, А.А. Краснобаев, Ф. Беа, П. Монтеро, Н.С. Бородина, В.В. Холоднов, Е.А. Зинькова, Г.Ю. Шардакова, С.В. Прибавкин. - Екатеринбург: ИГиГ Ур0 РАН, 2007. - С. 89-120.

27. Грабежев А.И. Sr-Nd-C-O-H-S изотопно-геохимическая характеристика медно-порфировых флюидно-магматических систем Южного Урала: вероятные источники вещества // Литосфера. - 2009. - № 6. - C. 66-89.

28. New data on the age and geodynamic position of copper-porphyry mineralization in the Main Uralian fault zone (South Urals) / A.M. Kosarev, V.N. Puchkov, I.B. Seravkin, V.V. Kholodnov, A.I. Grabezhev, Y.L. Ronkin // Doklady Earth Sciences. 2014. - № 1. - P. 1317-1321.

Поступила 29.05.2018 г.

\section{Информация об авторах}

Зайнуллин Р.И., младший научный сотрудник Института геологии Уфимского федерального исследовательского центра Российской академии наук; старший преподаватель Башкирского государственного университета. 


\title{
UDC 551.83; 552
}

\section{SEDIMENTATION OF LOCHKOVIAN-LOWER EMSIAN VOLCANOKLASTIC DEPOSITS OF THE WEST-MAGNITOGORSK ZONE OF THE SOUTH URAL}

\author{
Ruslan I. Zainullin ${ }^{1,2}$, \\ zri-bgu@mail.ru \\ 1 Institute of Geology - Subdivision of the Ufa Federal Research Centre of the Russian Academy of Sciences, \\ 16/2, Karl Marx street, Ufa, 457700, Russia \\ 2 Bashkir State University, \\ 32, Zaki-Validi street, Ufa, 450076, Russia.
}

The relevance of research. The Early Devonian stage of formation of the Magnitogorsk island-arc system remains poorly understood, despite the long history of research and rather large amount of data obtained. This stage corresponds to Lochkovian-Lower Emsian volcanoclastic, carbonate and siliceous rocks, widespread in the north of the West-Magnitogorsk zone. They are located in the zone of the Main Ural Fault and are therefore subject to secondary changes, and their sections have a fragmentary structure. Volcanoclastic rocks, the most widely spread, have not been studied. Their study and the study of facies relationships between them allows us to reconstruct the situation of sedimentation of the early Devonian basin and to detail the history of the development of the Magnitogorsk island arc system at the initial stage of its formation.

The main aim of this work is to identify the sources of demolition and sedimentation environments of the Lower Devonian volcaniclastic deposits of the West-Magnitogorsk zone of the Southern Urals.

Methods. Reconstruction of accumulation environments was carried out on the basis of studying structural and texture features, mineralogical-petrographic and lithogeochemical composition of volcaniclastic rocks and correlation of Lower Devonian deposits by biostratigraphic data. The results obtained were compared with the data of leading researchers on modern sedimentation environments.

Results. The Lower Devonian volcaniclastic deposits of the West-Magnitogorsk zone of the Southern Urals are turbidites and debris. They are composed mainly of pyroclastic and volcanic-terrigenous material of basalt and andesibasalt composition. It is shown that their accumulation took place in the proximal and distal part of the island arc. Deposits of the Itlibanskay and Mansurovskay strata were accumulated in the distal part, in the proximal - the Uskulskay and the Ryskuzhinskay strata. The formation of the Magnitogorsk islandarc system could begin in the early-ems time or even earlier.

\section{Key words:}

Volcaniclastic deposits, Lower Devonian, island arc, Magnitogorsk megazone, Southern Urals.

The research was carried out on the subject of the State task no. AAAA-A16-116090210010-5.

\section{REFERENCES}

1. Maslov V.A., Artyushkova 0.V. Stratigrafiya i korrelyatsiya devonskikh otlozheniy Magnitogorskoy megazony Yuzhnogo Urala [Stratigraphy and correlation deposits of Devonian of the Magnitogorsk megazone of Southern Urals]. Ufa, DizaynPoligrafServis Publ., 2010. 288 p.

2. Zaynullin R.I. Osobennosti sostava i stroeniya vulkanoklasticheskikh otlozheniy nizhnego devona severnoy chasti Zapadno-Magnitogorskoy zony Yuzhnogo Urala [Features of composition and structure of volcaniclastic deposits of the Lower Devonian in the northern part of the West-Magnitogorsk zone of the Southern Urals]. 2-ya Vserossiyskaya shkola studentov, aspirantov $i$ molodykh uchenykh po litologii.Unikalnye litologicheskie obekty cherez prizmu ikh raznoobraziya [2 $2^{\text {nd }}$ All-Russian school of students, postgraduates and young scientists of political science. Unique lithological objects through the prism of their diversity]. Ekaterinburg, 2016. pp. 122-124.

3. Zaynullin R.I. Composition and features of the formation of volcaniclastic deposits of the Lower Devonian of the Western Magnitogorsk zone of the Southern Urals. Lithosphere, 2017, vol. 17, no. 2, pp. 78-94. In Rus.

4. Ivanov K.S., Bikbaev A.Z., Mizens L.I., Sapelnikov V.P. Pervye nakhodki brakhiopod v vulkanogenno-osadochnykh porodakh irendykskoy svity na Yuzhnom Urale [First finds of brachiopods in volcano-sedimentary rocks of irendyksk formation in the Southern Urals]. Ezhegodnik 1996. Informatsionny sbornik nauchnykh trudov [Yearbook 1996. Information collection of scientific papers]. Ekaterinburg, Institute of Geology and Geochemistry, 1997. pp. 13-14.
5. Fazliakhmetov A.M., Artyushkova 0.V. Usloviya formirovaniya ranneemsskikh izvestnyakov vostochnogo sklona Yuzhnogo Urala po geokhimicheskim dannym [Conditions for formation of early Lima limestones of the eastern slope of the Southern Urals by geochemical data]. Osadochnaya geologiya Urala $i$ prilezhashchikh regionov: segodnya i zavtra. Materialy 12 Uralskogo litologicheskogo soveshchaniya [Sedimentary geology of the Urals and adjacent regions: today and tomorrow. Materials of the Ural lithological meeting]. Ekaterinburg, IGG UrB RAS Press, 2018. pp. 355-359.

6. Pavlov V.V. Geologicheskoe stroenie i poleznye iskopaemye Yuldashevskoy ploshchadi [Geological structure and minerals of Yuldashevskaya area]. Otchet o geologicheskom doizuchenii $v$ masshtabe 1:50000 za 1983-1988 gg. [Report on geological survey on a scale of 1:50000 for 1983-1988]. Ufa, Bashkirgeology, $1988.435 \mathrm{p}$.

7. Zaynullin R.I. Lower Devonian volcaniclastic deposits of the West-Magnitogorsk zone of the Southern Urals. Geology, geography and global energy, 2017, no. 4, pp. 74-89. In Rus.

8. Winchester J.A., Floyd P.A. Geochemical discrimination of different magma series and their differentiation products using immobile elements. Chem. Geol, 1977, vol. 20, pp. 325-343.

9. Frolova T.I., Burikova I.A. Magmaticheskie formatsii souremennykh geotektonicheskikh obstanovok [Magmatic formations of modern geotectonic environments]. Moscow, MGU, 1997. $320 \mathrm{p}$.

10. Martynov A.Y., Martynov Y.A. Pleistocene basaltic volcanism of Kunashir Island (Kuril island arc): Mineralogy, geochemistry, and results of computer simulation. Petrology, 2017, no. 2, pp. 206-225. 
11. Pearce J.A. Role of the sub-continental lithosphere in magma genesis at active continental margins. Continental basalts and mantle xenoliths. Eds. C.J. Hawkesworth, M.J. Norry. Nantwich, Sica Publ., 1983. pp. 230-249.

12. Mizens G.A., Svyazhina I.A. On paleogeography of the Urals in the Devonian. Lithosphere, 2007, no. 2, pp. 29-44. In Rus.

13. Dickinson W.R. Sedimentation of volcaniclastic strata of the Pliocene Koroimavua Group in northwest Viti Levu, Fiji, Am. J.Sci., 1968, vol. 266, pp. 440-453.

14. Mitchell A.H.G. Facies of an early Miocene volcanic arc, Malekula Island, New Hebrides. Sedimentology, 1970, vol. 14, pp. 201-243.

15. Carey S., Sigurdsson H. A model of volcanogenic sedimentation in marginal basins. London, Geological Society, 1984. Special Publications, vol. 16, pp. 37-58.

16. Carey S. Modeling of Tephra Fallout from Explosive Eruptions. Monitoring and Mitigation of Volcano Hazards. Berlin, Springer-Verlag Berlin Heidelberg, 1996. pp. 429-461.

17. Fisher R. Submarine volcaniclastic rocks. London, Geological Society, 1984. Special Publications, vol. 16, pp. 5-27.

18. Suthren R.J. Facies analysis of volcaniclastic sediments: a review. London, Geological Society, 1985. Special Publications, vol. 18, pp. 123-146.

19. Einsele G. Sedimentary basins: evolution, facies, and sediment budget. Berlin, Heidelberg, Springer, 2000. 792 p.

20. Einsele G. Sedimentary basins: evolution, facies, and sediment budget. Berlin, Heidelberg, Springer, 1992. 628 p.

21. Mizens G.A. Trace elements and features of the sources of detritus sedimentary formations Devonian and Carboniferous in the eastern areas of the South Urals. Geochemistry, 2009, no. 12 pp. 1259-1278.

22. Anisimov I.S. Mansurovskaya tolshcha: ee stroenie i polozhenie v geologicheskom razreze devona [Mansurovskaya stratum: its structure and position in the geological section of the Devonian]. Geologiya, poleznye iskopaemye i problemy geoekologii Bashkortostana, Urala $i$ sopredelnykh territoriy: materialy 9-y Mezhregio- nalnoy nauchno-prakticheskoy konferentsii [Geology, minerals and problems of geoecology of Bashkortostan, the Urals and adjacent territories: materials of the $9^{\text {th }}$ Interregional Scientific and Practical Conference]. Ufa, 2012. pp. 3-6.

23. Artyushkova 0.V., Maslov V.A. Nizhnedevonskie (doverhneemsskie) otlozheniya Magnitogorskoi megazony [Lower Devonian (Pre-upper Emsian) deposits of Magnitogorsk mega zone]. Geologicheskiy sbornik [Geological journal]. Ufa, IG USC RAS, 2001. pp. 80-87.

24. Kosarev A.M., Puchkov V.N., Seravkin I.B. Petrologico-geochemical features of early Devonian-Eifelian island-arc volcanics of the Magnitogorsk zone in the geodynamic context. Lithosphere, 2005, no. 4, pp. 22-41. In Rus.

25. Seravkin I.B., Kosarev A.M., Puchkov V.N. Geodynamic conditions of formation of massive sulfide deposits in the Magnitogorsk Megazone, Southern Urals, and prospection criteria. Geology of Ore Deposits, 2017, no. 3, pp. 227-243.

26. Fershtater G.B., Krasnobaev A.A., Bea F. Etapy paleozoyskogo intruzivnogo magmatizma Uralskogo orogena i ikh geodinamicheskaya interpretatsiya [Stages of Paleozoic intrusive magmatism of the Uralian orogen and their geodynamic interpretation]. Geodinamika, magmatizm, metamorfizm i rudoobrazovanie [Geodynamics, magmatism, metamorphism and ore formation]. Ekaterinburg, IGG UrO RAN, 2007. pp. 89-120.

27. Grabezhev A.I. Sr-Nd-C-O-H-S isotopic-geochemical characteristics of copper-porphyry fluid-magmatic systems of the Southern Urals: probable sources. Lithosphere, 2009, no. 6, pp. 66-89. In Rus.

28. Kosarev A.M., Puchkov V.N., Seravkin I.B., Kholodnov V.V., Grabezhev A.I., Ronkin Y.L. New data on the age and geodynamic position of copper-porphyry mineralization in the Main Uralian fault zone (South Urals). Doklady Earth Sciences, 2014, no. 1, pp. 1317-1321.

Received: 29 May 2018.

\section{Information about the authors}

Ruslan I. Zainullin, junior researcher, Institute of Geology - Subdivision of the Ufa Federal Research Centre of the Russian Academy of Sciences; senior lecturer, Bashkir State University. 